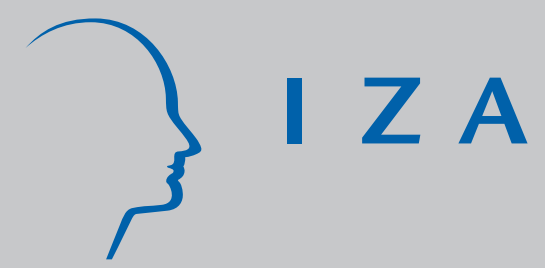

IZA DP No. 7208

Earnings Gap, Cohort Effect and Economic Assimilation of Immigrants from Mainland China, Hong Kong and Taiwan in the United States

Carl Lin

February 2013

Forschungsinstitut zur Zukunft der Arbeit Institute for the Study of Labor 


\title{
Earnings Gap, Cohort Effect and Economic Assimilation of Immigrants from Mainland China, Hong Kong and Taiwan in the United States
}

\author{
Carl Lin \\ Beijing Normal University \\ and IZA
}

Discussion Paper No. 7208

February 2013

IZA

P.O. Box 7240

53072 Bonn

Germany

Phone: +49-228-3894-0

Fax: +49-228-3894-180

E-mail: iza@iza.org

\begin{abstract}
Any opinions expressed here are those of the author(s) and not those of IZA. Research published in this series may include views on policy, but the institute itself takes no institutional policy positions. The IZA research network is committed to the IZA Guiding Principles of Research Integrity.

The Institute for the Study of Labor (IZA) in Bonn is a local and virtual international research center and a place of communication between science, politics and business. IZA is an independent nonprofit organization supported by Deutsche Post Foundation. The center is associated with the University of Bonn and offers a stimulating research environment through its international network, workshops and conferences, data service, project support, research visits and doctoral program. IZA engages in (i) original and internationally competitive research in all fields of labor economics, (ii) development of policy concepts, and (iii) dissemination of research results and concepts to the interested public.
\end{abstract}

IZA Discussion Papers often represent preliminary work and are circulated to encourage discussion. Citation of such a paper should account for its provisional character. A revised version may be available directly from the author. 


\section{ABSTRACT}

\section{Earnings Gap, Cohort Effect and Economic Assimilation of Immigrants from Mainland China, Hong Kong and Taiwan in the United States}

Using 1990, 2000 censuses and a 2010 survey, I examine the economic performance of ethnically Chinese immigrants from mainland China, Hong Kong and Taiwan (CHT) in the U.S. labor market. Since 1990, relative wages of $\mathrm{CHT}$ migrants have been escalating in contrast to other immigrants. I show these widening gaps are largely explained by individual's endowments, mostly education. Rising U.S.-earned degrees by CHT migrants can account for this relatively successful economic assimilation. Cohort analysis shows that the economic performance of $\mathrm{CHT}$ migrants admitted to the U.S. has been improving, even allowing for the effect of aging.

JEL Classification: J31, J61, J24

Keywords: Chinese immigration, economic assimilation, Oaxaca decomposition, synthetic cohort analysis

Corresponding author:

Carl Lin

School of Economics and Business Administration

Beijing Normal University

No.19 Xin Jie Kou Outer St.

Haidian Dist.

Beijing 100875

China

E-mail: csmlin@bnu.edu.cn 


\section{Introduction}

Although most narratives describing the early immigration waves to the U.S. often focus on European newcomers, Chinese migrants were also among the country's immigrants drawn by the economic boom associated with the California gold rush in the late 1840s. The Chinese Exclusion Act of 1882 banned most Chinese immigration to the country. It was not until the Immigration and Nationality Act of 1965 that legal Chinese immigration to the U.S. expanded significantly.

By source of origins, Chinese migrants came from different countries/regions and arrived in different time periods. Most of the ethnically Chinese immigrants came from mainland China, Hong Kong and Taiwan whereas some came from Singapore, Macau, Malaysia and few other parts of the world. These migrants behave differently, yet, they share common beliefs based on the key element of Chinese culture: Confucianism. Confucianism emphasizes that the importance of family, respect for hierarchy, good work ethics and moral principles are the cornerstone to keep society in good order. Especially, education is regarded as the core value. Over two thousand years, its influence has been over mainland China, Hong Kong, Taiwan, Korea, Japan, Vietnam, as well as various territories settled predominantly by Chinese migrants, such as Singapore.

Since 1980, legal migrants from mainland China, Hong Kong and Taiwan (CHT hereafter) admitted to the U.S. have grown steadily with an average of $1 / 2$ million people each decade. By 2010, there were 2.22 million immigrants from CHT and they represented the second-largest ${ }^{1}$ immigrant group in the U.S., accounting for $5.24 \%$ of the total immigrant population.

The evidence suggests that the economic outcomes of immigrants relative to natives in the U.S. have generally deteriorated since the 1960s (Borjas, 1999; Hanson, 2006). But, there are 
differences among immigrant groups. Rivera-Batiz (2007) shows immigrants from Latin America and the Caribbean (LAC hereafter) have substantially lower wages than other immigrants and the deterioration continues. Lin (2011) examines the economic performance of Taiwanese migrants who are relatively high-skilled and finds that they fare better and assimilate relatively successful in the U.S. labor market. These findings are all in concert with the claim by Borjas (1999): national origin matters.

Among CHT migrants in 2010, for example, immigrants from Hong Kong have relatively high earnings (average \$85,198) while those from Taiwan have the highest educational attainment (average 16.57 years). Mainland Chinese migrants earned lower wages than other immigrants in 1990 (-.74\% in hourly wage). After ten years, however, they surpassed their nonChinese cohorts in 2000 (10.84\% in hourly wage) and the gap widened in 2010 (18.31\% in hourly wage). In short, the economic outcomes of immigrants from CHT have notably improved relative to other immigrants since 1990 .

How do CHT migrant workers fare in the U.S.? Why have the labor market outcomes of CHT migrants improved and overtaken other migrants? Which of these factors, then, is most significant in explaining the trends in the economic outcomes of CHT migrants in the U.S.? Particularly, how does Chinese culture manifest itself in the process of migration and assimilation? This paper examines the explanations behind those changes, providing evidence on their relative importance.

\section{Trends in CHT Migration to the U.S. ${ }^{\wedge}$}

Legal Migration Flows from CHT to the U.S.

In 2010, legal migrants from CHT residing in the U.S. total over 2.22 million individuals. While the share of CHT migrants to all immigrants rose steadily, most of the increase came from 
mainland China. Immigrants from mainland China have grown an average of 1/2 million people, every ten years since 1990. By 2010, there were 1.6 million mainland Chinese residing in the U.S., $85 \%$ of them arrived after 1981.

The first major wave of immigrants from Hong Kong arrived in the 1960s, reached its peak of $25.68 \%$ in the $1980 \mathrm{~s}$, declined gradually to $25.30 \%$ in the 1990 s and dropped to $14.34 \%$ during 2001-2010. Migration from Taiwan to the U.S. began notably in the 1970s. Most of them (30.19\%) arrived in the 1980 s, and then declined to $21.02 \%$ in the $1990 \mathrm{~s}$ and $21.96 \%$ from 2001 to 2010. Major migration from China did not begin until the 1980s. About $30.96 \%$ of mainland Chinese arrived in the 1990s. During 2001-2010, the number increased to $39.42 \%$ which means roughly $40 \%$ of the immigrants from China entered the country after the millennium.

Occupation, Industry and Place of Work ${ }^{3}$

In the debate over immigration, the question of whether firms respond to immigration has an important policy implication. Native workers are not alone in responding to the changes in the economic environment induced by immigration. Both native- and foreign-owned firms will also want to take advantage of these changes. A well-known fact is that immigrants enter occupations and industries which differ from the occupations and industries that employ the native work force (Borjas, 1999). Moreover, immigrants enter different occupations and industries among themselves. Immigration does tend to change the skill composition of the work force in the immigrant-receiving area, possibly altering the industrial structure of the region (Borjas et al., 1997).

Compared to other immigrants and natives in 1990, 2000 and 2010, CHT migrants are overrepresented in white-collar jobs such as managerial and professional specialties, particularly for Taiwanese migrants. On the other hand, CHT migrants are under-represented in precision 
production, craft, repair, and also in farming, forestry and fishing. Notice that mainland Chinese are more likely to enter service occupation which is roughly similar to other immigrants. Looking at industries, there are few CHT migrants in the agricultural, forestry, fisheries and mining sector. Among all, a notable difference is that mainland Chinese migrants are relatively more in the retail/sales/trade sector compared to other CHT migrants, other immigrants, and natives.

Immigrants in the U.S. tend to settle in a limited number of states and cities. This geographic concentration seems to have increased over time. This fact reflects both the immigrants' propensity to enter the U.S. through a limited number of gateway cities and they-unlike natives — do not seem to move much around the country (Borjas, 1999; Card and Shleifer, 2009). Bartel (1989) finds that once immigrants enter one of the gateway cities, they tend to stay there. The evidence of CHT migrants supports the above findings and shows that they are more likely to work in one of the five main metropolitan areas. ${ }^{\wedge}$

\section{Educational Attainment}

Decades of social science research have shown that there is a strong and irrefutable link between human capital—an individual's endowment of ability and acquired skills—and social and economic outcomes, which include potential earnings, work effort, assimilation, criminal activity, drug abuse and life expectancy, etc. (Borjas, 1999). In the immigration literature, the seminal works of Chiswick (1978) and Borjas (1985) have established that the skill composition of the immigrant population (and how the skills of immigrants compare to those of natives) determines the social and economic consequences of immigrants.

An important fact of the trend in immigrant skills in the U.S. is the relative educational attainment and economic performances of the immigrant population have changed since 1960. 
The literature has shown that in 1960 immigrant workers, on average, earn more than native workers but since 1990, the educational attainment and wages of immigrants have lagged (Autor and Katz, 1999; Borjas, 1999; Rivera-Batiz, 2007). Furthermore, Autor et al. (2008) and Lemieux (2008) find increased polarization earnings differentials (top- and bottom-ends) in the U.S. labor market since 1990.

Compared to other immigrants and natives, CHT migrants have relatively high educational attainments. In 1990, 35\% of CHT migrants have more than a bachelor's degree (16\% of other immigrants, $14 \%$ of natives), then increases to $42 \%$ and $44 \%$ in 2000 and 2010 , respectively (19\% and $22 \%$ for other immigrants, $16 \%$ and $19 \%$ for natives). Within CHT migrants, immigrants from Taiwan have remarkably high educational attainment. For instance, those who have graduate degrees increase from $26.23 \%$ in 1990 , to $30.13 \%$ in 2000 , and to $33.59 \%$ in 2010 . How Have CHT Migrant Fared in the U.S. Labor Market?

To show how the labor market performance of CHT migrants has changed over time, Figure 1 plots relative wages of several immigrant groups between 1990 and 2010. The bifurcation is vividly illustrated: relative wages of other immigrants, Mexico and LAC (excl. Mexico) to natives have been deteriorating, while those of CHT migrants have been improving. On the other hand, unreported table shows that immigrants from CHT have relatively lower unemployment rate and their labor force participation rates are stable across time.

"INSERT Figure 1 here."

\section{The Earnings of Immigrants}

\section{Data and Summary Statistics}

As section 2 shows, immigrants from CHT have fared better than other immigrants in the past two decades. This section uses data drawn from the 1990, 2000 U.S. decennial censuses and the 
2010 American Community Survey (ACS hereafter) to analyze their labor market performance and provide explanations to the improvements. The appendix provides a detailed description of the construction of the data extracts and of the variables used in the analysis. To make analysis comparable, observations of CHT migrants are excluded from other immigrants.

The empirical framework follows the standard immigration literature by Chiswick (1978) and Borjas (1985) that the natural logarithm of the earnings of a worker $i$ is given by $\ln E_{i}=\beta^{\prime} X_{i}+U_{i}$, where dependent variable $\ln E_{i}$ is the natural logarithm of earnings of worker $i, \beta$ is a vector of coefficients to be estimated, $X_{i}$ is a vector of individual human capital and demographic characteristics affecting earnings of worker $i$, and $U_{i}$ is a stochastic disturbance term. Human capital and demographic variables included in the vector $X_{i}$ are as the following. First of all, education and experience and its square term are used as proxies for human capital. Education is expected to have a positive effect on earnings, while the effect of experience is assumed to initially rise and then fall. Second, English language proficiency ${ }^{\wedge}{ }^{5}$ has been found to be a key human capital variable influencing the earnings of immigrants. Employment opportunities may be severely limited if the immigrant's knowledge of the English language is not sufficient (Borjas, 1999). English proficiency on labor market outcomes generally finds a positive impact on earnings (Rivera-Batiz, 1990; Chiswick and Miller, 1999). Third, usual hours worked can be expected that, holding other things constant, increased hours of work per week will be associated with higher earnings. Fourth, married with spouse present is the marital status variable. Chiswick (1978) finds that married men tend to have higher labor force participation rates, invest more in human capital, and have better health than men who are not married. For the same age, schooling, and place of residence, married men have higher earnings. Fifth, work in metropolitan areas usually earns more than work in rural areas. Sixth, years since migration and 
its square term. Chiswick (1978, 1999), Duleep and Regets (1999) and Rivera-Batiz (2007) have suggested that with limited knowledge about labor market institutions in the U.S., recent migrants may accept jobs with wage offers lower than those they would otherwise accept given their skills. As their stay increases and they are able to search for better-paying jobs, earnings will rise and they will be paid wages that correspond more closely to their skill endowments.

Table 1 reports the summary statistics of all variables used in the analysis. It shows that the average annual earnings of CHT migrants are higher than other immigrants and natives in each year and the differentials become larger. Education, calculated by completed years of schooling, is the key explanatory variable. The differences between CHT migrants and other immigrants are 2.7 years in 1990 and 3.2 years in 2000 and 2010. Notice that Taiwanese migrants have the highest years of schooling (over 16 years in each survey). For labor market experience, each immigrant group has similar years. In English language proficiency, CHT migrants, on average, are much the same as other immigrants. Mainland Chinese migrants, however, possess relatively lower language skill. As to marital status, $\mathrm{CHT}$ migrants are more likely to be married than other immigrants and natives. For place of work, over $90 \%$ of $\mathrm{CHT}$ migrants work in metropolitan areas in all survey years. CHT migrants have similar years since migration compared to other immigrants. Although mainland Chinese migrants have relatively lower earnings and language skills, their rapid economic assimilation experience is particular of interest in this paper.

"INSERT Table 1 here."

\section{Empirical Analysis}

Table 2 reports the results of the empirical analysis. For the convenience of comparing the effects of explanatory variables on earnings across immigrants and across time, I group the OLS estimated coefficients from the earnings equations for immigrants of mainland China, Hong 
Kong, Taiwan, CHT, and other immigrants by year. The signs of the regression coefficients on the explanatory variables are generally identical and are in line with the theoretical expectations. Nevertheless, there are some significant differences in the magnitude of the coefficients.

\section{"INSERT Table 2 here."}

The return to education for CHT migrants has been rising over time and overtaken other immigrants in 2000. In 1990, holding other variables constant, one more year of schooling increases CHT migrants' earnings for 5.2\% (5.5\% for other immigrants). In 2000, the numbers raise to $8.4 \%$ (6.7\% for other immigrants) and to $9.5 \%$ ( $7.3 \%$ for other immigrants) in 2010 . The education factor is particularly evident for mainland Chinese and Taiwanese migrants. Although the English language proficiency of CHT migrants and other immigrants are similar as reported in Table 1, the coefficients of English Very Well turn positive for mainland Chinese. Despite only the coefficient of 2000 is significant, this may suggest language is one of the major barriers for mainland Chinese who recently move to the U.S. This can be seen from the relatively larger coefficients (in absolute value) of English Not Well and English Not At All in all three years. Once their English improves, the return of language skill increases quickly (Rivera-Batiz, 1990; Chiswick and Miller, 1999). The effects of place of work are relatively strong for Hong Kong and they don't seem to be important for Taiwan. Lastly, years since migration have larger effects on the earnings of CHT migrants than other immigrants.

The empirical results show that education plays a key role in the better performance of CHT migrants in the U.S. labor market. ${ }^{\wedge}{ }^{6}$ After accounting for sample selection issues ${ }^{\wedge}$, I investigate why this occurs and provide explanations behind the change.

\section{Explaining The Earnings Gap}

\section{Decomposing the Gap}


The dispersion in individual earnings or wages can be estimated as in the standard earnings function, which can be simply rewritten and estimated separately for the two demographic groups as $\ln Y_{i}^{g}=\beta_{0}^{g}+\sum_{j=1}^{n} \beta_{j}^{g} X_{j i}^{g}+U_{i}^{g}$, where $X_{1 i} \ldots \ldots . X_{n i}$ are $n$ observable characteristics used to explain the natural logarithm of earnings $(\ln Y), g=a$ denotes other immigrants and $g=b$ denotes CHT migrants. I compute the portion of the differentials explained by the regression and rewrite the equation as $\sum_{j} \beta_{i}^{b} \bar{X}_{j i}^{b}-\sum_{j} \beta_{i}^{a} \bar{X}_{j i}^{a}=\sum_{j} \beta_{j}^{b}\left(\bar{X}_{j}^{b}-\bar{X}_{j}^{a}\right)+\sum_{j} \bar{X}_{j}^{a}\left(\beta_{j}^{b}-\beta_{j}^{a}\right)$, where the first term on the right hand side is the "characteristics effects" while the second is the "coefficients effects".

Table 3 reports the decomposition results. I decompose the earnings gap (in log earnings) between each immigrant group of CHT and other immigrants in 1990, 2000, and 2010. For example, the log earnings of mainland Chinese and other immigrants in 2010 are 5.988 and 5.710 , respectively. This .278 earnings differential, which is reported in the third column, can be decomposed into .220 ( $79 \%$ is explained by characteristics) and $.058(21 \%$ is explained by coefficients). As Table 3 shows, most of the earnings gaps between CHT migrants and other immigrants are attributable to characteristics effects. The better endowments/characteristics of CHT migrants can account for most of the earnings gap and the importance increases over time. I further decompose the two parts, "characteristics effects" and "coefficients effects" for each factor, to see what contributes the most to the gaps.

"INSERT Table 3 here."

A related issue that has received attention in the literature is that detailed decomposition is not invariant to the choice of the reference category when sets of dummy variables are used (Jones and Kelley, 1984; Oaxaca and Ransom, 1999; Horrace and Oaxaca, 2001; Gardeazabal 
and Ugidos, 2004; Yun, 2005; Jann, 2008). If a model includes dummy variables, then the sum of the detailed coefficients effects attributed to the dummy variables is not invariant to the choice of the reference, or omitted, category (Powers et al., 2011). Since I have several categorical variables in my regressions, I apply the solution proposed by Gardeazabal and Ugidos (2004) and Yun (2005) and implement the method in Jann (2008).

Table 3 also shows the detailed decomposition results. Education accounts for most of the differentials in characteristics and coefficients for all groups and years. For example, as I already show $88 \%$ of the .192 log earnings gap between CHT migrants and other immigrants can be due to difference in endowments in 1990. Detailed decomposition further shows $80 \%$ of the characteristics effects can be attributed to education. In sum, the contributions of education to the earnings gap are substantial across time (80\% in 1990, 79\% in 2000 and $78 \%$ in 2010).

\section{U.S.-Earned Degrees}

The research of Chiswick $(1978,1999)$ and Duleep and Regets (1999) has suggested that immigrants face an initial shortfall or dip in their labor market performance after they arrive in the country. This dip is the result of the adjustment costs that recent immigrants, with limited knowledge about labor market institutions, suffer as they enter the U.S. Borjas (1999) states that in order to experience economic assimilation, an immigrant will often have to acquire skills that are valued by American employers. After arriving in the U.S., immigrants add to their human capital in many ways, such as learning the English language, obtaining U.S. degrees, enrolling in on-the-job training programs, and so on. My analysis so far has pointed out that education is the most important contributing factor to the relatively successful economic assimilation of CHT migrants. An important question, then, to ask is: how many acquire U.S. degrees after arriving? How do the numbers/percentages change overtime? 
The bottom panel of Figure 1 plots the percentages of total U.S.-earned degrees ${ }^{\wedge}$ of several immigrant groups from 1990 to 2010. The upward trend is remarkable for CHT migrants. In 1990, total U.S.-earned degrees of mainland China, Hong Kong and Taiwan ranged between 6\%9\% while other immigrants, LAC (excl. Mexico) and Mexico were from $16 \%-21 \%$. The difference was over 10\%. However, as Figure 1 shows, in 2000 the gap narrowed both because the CHT group kept rising and the other group slowed down (Mexico dropped from 21\% to 19\%). From 2000 to 2010, all immigrant groups rose steadily. In sum, the rising U.S.-earned degree of CHT migrants can, in some parts, explain why they are relatively successful in assimilating into the U.S. labor market.

\section{Cohort and Aging Effects}

The empirical results so far have shown the strong economic assimilation of CHT migrants into the U.S. labor market. These are based on cross-section regressions over 1990 to 2010. Borjas (1985) stresses the differences between cross-section and cohort analyses of earnings determination. In particular, cross-section studies of immigrant earnings growth confound the true assimilation impact with across-cohort changes in immigrants' economic performance. In addition, the cross-section analysis does not account for the effects of aging on the impact of assimilation. In this section I examine how these two effects can affect my findings.

\section{Cohort Analysis $^{\wedge}$}

Consider cohort $h$, the 2010 regression predicts that over ten years the "cross-section" growth for cohort $h$ is given by

$$
\hat{Y}_{2010, h}-\hat{Y}_{2010, h+10}=\left(\hat{Y}_{2010, h}-\hat{Y}_{2000, h}\right)+\left(\hat{Y}_{2000, h}-\hat{Y}_{2010, h+10}\right),
$$

where $\hat{Y}$ is the estimated value of the natural log of earnings. The first term on the right hand side of (1) gives the earnings growth experienced by cohort $h$ over the ten years and is called the 
"between-census" growth. The second term on the right hand side estimates the difference in earnings that occurred over the ten years for individuals with a given number of years since immigration. It compares different cohorts at the same point of their U.S. life cycle and is called the "across-cohort" earnings growth (Borjas, 1985). Therefore, equation (1) illustrates the comparison of immigrant cross sections over time can be used to infer the extent to which the underlying assimilation process of immigrant cohorts is changing.

To account for the effect of secular changes in aggregate labor market condition, the crosssection growth in the relative earnings of immigrant cohort $h$ to native workers $n$ is

$$
\hat{\beta}_{h}-\hat{\beta}_{h+10}=\left[\left(\hat{Y}_{2010, h}-\hat{Y}_{2010, n}\right)-\left(\hat{Y}_{2000, h}-\hat{Y}_{2000, n}\right)\right]+\left[\left(\hat{Y}_{2000, h}-\hat{Y}_{2000, n}\right)-\left(\hat{Y}_{2010, h+10}-\hat{Y}_{2010, n}\right)\right] .
$$

The first bracketed term in (2) gives the difference in the relative earnings of cohort $h$ between 2010 and 2000. This between-census effect measures the rate at which the earnings profiles of immigrants and natives are converging/diverging (Borjas, 1985). The second bracketed term in (2) gives the across-cohort effect.

Table 4 reports the cohort analysis results from equation (1) and (2). In addition to 2010 ACS, I also estimate both equations using 2000 census data. The result of interest is the sign in the "across-cohort" growth panel which compares the ten years labor market performance between an old cohort $h$ and a recent cohort $h+10$. A negative sign of "across-cohort" growth means giving both cohorts ten years to work in the U.S., the earnings growth of the old cohort is less than those of the recent cohort. In other words, it implies the economic performance of the recent cohort is better if the sign of "across-cohort" growth is negative. For instance, if one look at the three recent cohort differences of "1990-1999 minus 2000-2009”, “1980-1989 minus 19901999”, and “1970-1979 minus 1980-1989” in Table 4, 16 out of 20 in the absolute earnings cases have negative signs. In addition, 15 out of 20 in the relative earnings cases also have negative 
signs which mean after accounting for the labor market conditions, the relative cohort analysis shows a better economic performance for each CHT migrant group. ${ }^{\wedge} 10$

"INSERT Table 4 here."

\section{Aging Effect}

In any cross section, the effect of aging must be taken into account when studying the determinants of earnings. If the potential labor market experience coefficients are roughly similar, the effect of aging on the relative earnings of immigrants would not be very important. But the regression results in Table 4 do not show such case. Therefore, it is necessary to estimate how much aging effect may affect my results. Following Borjas (1985), the change in the relative earnings of immigrants to natives due purely to aging effect can be shown as

$$
A_{i}-A_{n}=10\left(\hat{\beta}_{E X P, i}-\hat{\beta}_{E X P, n}\right)+\left(\hat{\beta}_{E X P^{2}, i}-\hat{\beta}_{E X P^{2}, n}\right)(20 E X P-100)
$$

The bottom panel of Table 4 reports the aging effect using (3). In 28 out of 32 cases, pure aging effects lead to a decrease of the relative earnings of CHT migrants over time. For immigrant men that are 10 years older in 2010 than in 2000 lowers the relative earnings of CHT migrants by $8 \%-18.2 \%$. For immigrant men that are 10 years older in 2000 than in 1990 lowers the relative earnings of CHT migrants by $13.7 \%-18.7 \% .{ }^{\wedge 11}$ When these quantities are added to the between-census growth presented in Table 4, the relative earnings and assimilation rate of CHT migrants, as a result, reduce by aging effect. Despite the fact that pure aging effects do not work in favor of CHT migrants, it does not alter the outcome of relatively better labor market performance by CHT migrants to other immigrants from other parts the world.

\section{Conclusions}

This paper examines the economic performance of ethnically Chinese immigrants in the U.S. labor market from 1990 to 2010 . The empirical results show the earnings of immigrants from 
mainland China, Hong Kong and Taiwan have grown rapidly as they assimilate into the U.S. while immigrants from other parts of the world show the opposite. The analysis has three major findings: 1 . The widening earnings gaps between CHT migrants and other immigrants are largely explained by endowments/characteristics, mainly due to differences in skills. Detailed decomposition shows that education can account for $80 \%$ of the differences in endowments/characteristics; 2 . The evidence of rising U.S.-earned degrees by CHT migrants can explain this relatively successful economic assimilation; 3. Cohort analysis shows that the economic performance of CHT migrants has been improving even if allowing for aging effect.

Though CHT migrants behave differently, within the group I find there are economically important shared beliefs. Not only national origin matters, but culture plays a central role in the understanding of migration as an economic phenomenon (Epstein and Gang, 2010). Chinese culture's emphasis on the importance of education and family well reflects the relatively successful economic performance of CHT migrants in the U.S.

\section{Appendix: Data and Variable Definitions}

The data are drawn from the 1990, 2000 Public Use Microdata Samples of the U.S. Census, and the 2010 American Community Survey from IPUMS-USA (Ruggles et al., 2010). In 1990 and 2000 the data extracts form a 5\% random sample of the population. The analysis is restricted to men aged 18-64. A person is classified as an immigrant if he was born abroad and is either a noncitizen or a naturalized citizen; all other persons are classified as natives. People who were born in American Samoa, Guam, Puerto Rico, U.S. Virgin Islands, unknown or at sea are excluded from the analysis. Sampling weights are used in all calculations.

\section{Definition of Annual Earnings}

These variables are calculated in the sample of men who do not reside in group quarters, are 
employed in the civilian labor force, are not enrolled in school, report positive annual earnings, weeks worked, and weekly hours, and are not self-employed.

\section{Definition of Weeks Worked Last Year}

In the 2010 ACS, weeks worked in the calendar year prior to the survey are reported as a categorical variable. I impute weeks worked for each worker as follows: 7 for 13 weeks or less, 20 for 14-26 weeks, 33 for 27-39 weeks, 43.5 for 40-47 weeks, 48.5 for 48-49 weeks, and 51 for 50-52 weeks.

\section{Definition of Education and Experience}

Because of differences in the coding of the completed education variable across surveys, in order to compute completed years of education, in 1990 census I assign 2.5 for grade 1, 2, 3, or 4, 6.5 for grade 5, 6, 7, or 8, 12 for grade 12 and high school graduate or GED. In 2000 census, I assign 2.5 for nursery school to grade $4,5.5$ for grade 5 or $6,7.5$ for grade 7 or $8,12.5$ for some college but less than 1 year.

In all surveys, I assign a one or more years of college credit but no degree 13 years, an associate's degree 14 years, and a bachelor's degree 16 years. Those who have a master's degree are given 18 years, a professional degree beyond a bachelor's degree are given 19 years, and a doctoral degree corresponded to 20 years of education.

I define work experience as the worker's age at the time of the survey minus years of completed education minus 6 . I restrict the analysis to persons who have between 1 and 45 years of experience.

\section{References}

Autor, David H. and Lawrence F. Katz, "Chapter 26 Changes in the Wage Structure and Earnings Inequality," in Orley C. Ashenfelter, and David Card (ed.), Handbook of Labor Economics, 
Elsevier, 1999.

Autor, David H., Lawrence F. Katz and Melissa S. Kearney, "Trends in U.S. Wage Inequality: Re-Assessing the Revisionists," Review of Economics and Statistics 90 (2008): 300-23.

Bartel, Ann P., "Where Do the New U.S. Immigrants Live?," Journal of Labor Economics 7 (1989): 371-91.

Borjas, George J., "Assimilation, Changes in Cohort Quality, and the Earnings of Immigrants," Journal of Labor Economics 3 (1985): 463-89.

—, Heaven's Door: Immigration Policy and the American Economy Princeton, N.J.: Princeton University Press, 1999.

Borjas, George J., Richard B. Freeman and Lawrence F. Katz, "How Much Do Immigration and Trade Affect Labor Market Outcomes?," Brookings Papers on Economic Activity 28 (1997): 190.

Card, David and Andrei Shleifer, "Immigration and Inequality," American Economic Review 99 (2009): 1-21.

Chiswick, Barry R., "The Effect of Americanization on the Earnings of Foreign-Born Men," Journal of Political Economy 86 (1978): 897-921.

—_, "Are Immigrants Favorably Self-Selected?," American Economic Review 89 (1999): $181-5$.

Chiswick, Barry R. and Paul W. Miller, "Language Skills and Earnings among Legalized Aliens," Journal of Population Economics 12 (1999): 63-89.

— Journal of Economy and Society 48 (2009): 454-65.

Duleep, Harriet Orcutt and Mark C. Regets, "Measuring Immigrant Wage Growth Using 
Matched CPS Files," Demography 34 (1997): 239-49.

—_, "Immigrants and Human-Capital Investment," American Economic Review 89 (1999): $186-91$.

—, "The Elusive Concept of Immigrant Quality: Evidence from 1970-1990," IZA Discussion Paper No. 631 (2002).

Epstein, Gil S. and Ira N. Gang, "Chapter 1 Migration and Culture," in Gil S. Epstein, and Ira N. Gang (ed.), Migration and Culture, Emerald Group Publishing Limited, 2010.

Gardeazabal, Javier and Arantza Ugidos, "More on Identification in Detailed Wage Decompositions," The Review of Economics and Statistics 86 (2004): 1034-36.

Hanson, Gordon H., "Illegal Migration from Mexico to the United States," Journal of Economic Literature 44 (2006): 869-924.

Heckman, James J., "The Common Structure of Statistical Models of Truncation, Sample Selection and Limited Dependent Variables and a Simple Estimator for Such Models," Annals of Econometrics and Social Measurement 5 (1976): 120-37.

Horrace, William C. and Ronald L. Oaxaca, "Inter-Industry Wage Differentials and the Gender Wage Gap: An Identification Problem," Industrial and Labor Relations Review 54 (2001): 61118.

Jann, Ben, "A Stata implementation of the Blinder-Oaxaca decomposition," ETH Zurich Sociology Working Papers 5, Chair of Sociology, ETH Zurich, (2008).

Jones, F. L. and Jonathan Kelley, "Decomposing Differences between Groups: A Cautionary Note on Measuring Discrimination," Sociological Methods and Research 12 (1984): 323-43.

Lemieux, Thomas, "The Changing Nature of Wage Inequality," Journal of Population Economics 21 (2008): 21-48. 
Lin, Carl, "Migration and Capital Market Event," Ph.D. dissertation, Rutgers University, 2011.

Oaxaca, Ronald L. and Michael R. Ransom, "Identification in Detailed Wage Decompositions," The Review of Economics and Statistics 81 (1999): 154-7.

Powers, Daniel A., Hirotoshi Yoshioka and Myeong-Su Yun, "mvdcmp: Multivariate Decomposition for Nonlinear Response Models," Stata Journal 11 (2011): 556-76.

Ruggles, Steven, J. Trent Alexander, Katie Genadek, Ronald Goeken, Matthew B. Schroeder and Matthew Sobek, "Integrated Public Use Microdata Series: Version 5.0 [Machine-readable database]," Minneapolis: University of Minnesota, 2010.

Rivera-Batiz, Francisco L., "English Language Proficiency and the Economic Progress of Immigrants," Economics Letters 34 (1990): 295-300.

— Market?," The World Economy 30 (2007): 1399-429.

Yun, Myeong-Su, "A Simple Solution to the Identification Problem in Detailed Wage Decompositions," Economic Inquiry 43 (2005): 766-72.

\section{Notes}

1. The largest immigrant group is from Mexico which has 12 million individuals residing in the U.S., $28.23 \%$ of total immigrant population in 2010. Mexico (28.23\%), Philippines (4.48\%), India (4.29\%), China (3.85\%), Vietnam (3.01\%), El Salvador (2.89\%), Germany (2.81\%), South Korea $(2.70 \%)$ and Cuba (2.67\%) are the top nine sending countries, each having more than 1 million migrants in the U.S. by 2010.

2. The analysis in this section uses data drawn from the 1990 and 2000 U.S. decennial censuses, as well as the 2010 American Community Survey.

3. The tables in this section are not reported, however, they are available upon request. 
4. In $2010,37 \%(39 \%$ in $2000,43 \%$ in 1990$)$ of CHT migrants work in one of the five metropolitan areas: New York-Northeastern New Jersey, Los Angeles-Long Beach, San Francisco-Oakland-Vallejo, San Jose and Oakland of California. The order has not changed since 1990.

5. An index from 0 to 4. 0: Dose not speak English. 1: Yes but not well. 2: Yes, well. 3. Yes, very well. 4. Yes, speaks only English. Table 1 reports the average of the index. Table 2 reports the four dummy variables in the regression where Speaks only English is omitted to avoid collinearity.

6. Although I analyze the occupations of each immigrant group in section 2, occupations do not enter my regression analysis as suggested in Chiswick and Miller (2007, 2009). Instead, I use mean occupational earnings as the dependent variable to account for the fact of differing occupations among CHT migrants and other immigrants. Though I do not report the OLS and ordered probit/logit results, it does not affect the main conclusions of the paper. Earnings and occupational attainment results are available upon request.

7. I use the two-step procedure based on the work of Heckman (1976) to check for two sample selection issues: decision to work and self-employment. The insignificance of all inverse Mill's ratio coefficients indicate that my regressions do not suffer from the sample selection problem. In addition, unreported results of regression on females (as well as decomposition, cohort analysis and aging effects) show similar outcomes as males. In short, my sample selection rules should yield consistent results and won't lead to different conclusions.

8. I use variables MIGRATE1 in 2001 to 2010 ACS and MIGRATE5 in 2000 and 1990 censuses to determine whether an immigrant obtains his/her highest degree in the U.S. If the immigrant was abroad one year ago and is a high school graduate when interviewed, the reported 
educational attainment is not U.S.-earned. The number of 2010 is the average from 2001 to 2010. 9. There have been concerns about the results of Borjas (1985). Using matched Current Population Surveys and 1970-1990 censuses, Duleep and Regets $(1997,2002)$ find different results showing that immigrant year-to-year earnings growth rates are greater than natives in true panel data and they present strong evidence of a systematic and inverse relationship (correlation .489 for 1980-1990) between entry earnings of immigrants and subsequent earnings growth. Following Duleep and Regets (2002), I group countries, age and education each into two categories and find the correlation between the relative entry earnings (w.r.t. natives) of the country/age/education cohorts and their 2000-2010 real earnings growth rates is -.295 ( -.284 for 1990-2000, -.272 for $1980-1990$, and -.221 for 1970-1980). A statistically significant estimated relationship suggests a .1 unit decrease of relative entry earnings would raise the real earnings growth rate by $4.13 \%$ and $3.04 \%$ for $2000-2010$ and $1990-2000$, respectively. Though the sample size is small (24 cells in my data compared to 96 cells in Duleep and Regets, 2002), the results reinforce the conclusion of this section.

10. In the relative earnings cohort analysis, the choice of reference group can be tricky. Borjas (1985) compares immigrants' earnings to their native counterparts and finds little difference. In addition to using all natives as the reference group, I also use Chinese American as CHT migrants' native counterparts. The results also show a better performance of recent CHT migrants.

11. These numbers are close to Borjas (1985) which is $12 \%$ to $15 \%$ for Asian immigrants. 
Table 1. Summary Statistics

\begin{tabular}{|c|c|c|c|c|c|c|c|c|c|c|c|c|c|}
\hline \multirow{2}{*}{ Variables } & \multirow{2}{*}{ Year } & \multicolumn{2}{|c|}{$\begin{array}{l}\text { Mainland } \\
\text { China }\end{array}$} & \multicolumn{2}{|c|}{ Hong Kong } & \multicolumn{2}{|c|}{ Taiwan } & \multicolumn{2}{|c|}{ CHT } & \multicolumn{2}{|c|}{$\begin{array}{c}\text { Other } \\
\text { Immigrants }\end{array}$} & \multicolumn{2}{|c|}{ Natives } \\
\hline & & Mean & S.D. & Mean & S.D. & Mean & S.D. & Mean & S.D. & Mean & S.D. & Mean & S.D. \\
\hline \multirow{3}{*}{$\begin{array}{l}\text { Earnings } \\
\text { (dollar) }\end{array}$} & 2010 & 60,354 & 58,970 & 85,198 & 70,243 & 84,152 & 68,370 & 67,657 & 63,170 & 45,316 & 52,979 & 56,625 & 56,002 \\
\hline & 2000 & 54,867 & 54,761 & 74,234 & 72,981 & 83,767 & 71,817 & 64,329 & 63,271 & 47,140 & 55,493 & 57,385 & 57,054 \\
\hline & 1990 & 47,788 & 44,726 & 56,247 & 44,936 & 64,975 & 49,129 & 53,638 & 46,477 & 44,266 & 42,505 & 51,359 & 41,503 \\
\hline \multirow{3}{*}{$\begin{array}{l}\text { Log of } \\
\text { Earnings } \\
\text { (dollar) }\end{array}$} & 2010 & 5.99 & .98 & 6.44 & .86 & 6.40 & .95 & 6.12 & .98 & 5.71 & .91 & 5.98 & .93 \\
\hline & 2000 & 5.91 & .95 & 6.26 & .88 & 6.43 & .84 & 6.08 & .95 & 5.77 & .90 & 6.05 & .81 \\
\hline & 1990 & 5.80 & .92 & 6.04 & .85 & 6.20 & .83 & 5.94 & .90 & 5.75 & .88 & 5.98 & .79 \\
\hline \multirow{3}{*}{ Education } & 2010 & 14.78 & 4.57 & 15.55 & 2.83 & 16.57 & 2.54 & 15.20 & 4.14 & 12.05 & 4.23 & 13.74 & 2.44 \\
\hline & 2000 & 14.52 & 4.77 & 14.97 & 3.23 & 16.68 & 2.84 & 15.07 & 4.28 & 11.84 & 4.53 & 13.52 & 2.44 \\
\hline & 1990 & 12.89 & 5.13 & 14.36 & 4.12 & 16.27 & 4.12 & 14.00 & 4.93 & 11.29 & 5.01 & 12.89 & 3.33 \\
\hline \multirow{3}{*}{ Experience } & 2010 & 21.65 & 11.12 & 22.53 & 10.60 & 21.45 & 10.27 & 21.72 & 10.91 & 21.43 & 10.90 & 21.82 & 11.80 \\
\hline & 2000 & 21.00 & 11.20 & 18.19 & 9.41 & 17.93 & 9.38 & 19.87 & 10.64 & 19.46 & 10.62 & 20.34 & 10.95 \\
\hline & 1990 & 24.36 & 10.34 & 14.15 & 8.63 & 15.59 & 8.64 & 20.31 & 10.71 & 19.45 & 10.94 & 19.04 & 11.22 \\
\hline \multirow{3}{*}{ Language } & 2010 & 1.99 & 1.07 & 2.75 & .80 & 2.61 & .89 & 2.20 & 1.05 & 2.27 & 1.20 & - & - \\
\hline & 2000 & 2.03 & 1.04 & 2.59 & .84 & 2.55 & .78 & 2.24 & .99 & 2.37 & 1.21 & - & - \\
\hline & 1990 & 1.93 & 1.07 & 2.56 & .80 & 2.42 & .77 & 2.17 & 1.00 & 2.49 & 1.20 & - & - \\
\hline \multirow{3}{*}{$\begin{array}{l}\text { Usual Hours } \\
\text { Worked Per } \\
\text { Week }\end{array}$} & 2010 & 42.61 & 10.37 & 42.88 & 9.76 & 43.48 & 10.16 & 42.80 & 10.26 & 41.52 & 9.55 & 42.92 & 10.35 \\
\hline & 2000 & 43.56 & 10.86 & 44.04 & 10.34 & 44.29 & 10.47 & 43.80 & 10.70 & 43.43 & 10.12 & 44.35 & 9.89 \\
\hline & 1990 & 44.10 & 13.21 & 43.48 & 10.17 & 42.90 & 9.49 & 43.69 & 10.92 & 43.00 & 10.25 & 43.70 & 9.80 \\
\hline \multirow{3}{*}{$\begin{array}{l}\text { Married with } \\
\text { spouse } \\
\text { present }\end{array}$} & 2010 & .71 & .47 & .69 & .46 & .71 & .45 & .71 & .46 & .56 & .50 & .57 & .49 \\
\hline & 2000 & .74 & .44 & .66 & .48 & .73 & .45 & .73 & .45 & .59 & .49 & .63 & .48 \\
\hline & 1990 & .78 & .41 & .60 & .49 & .77 & .42 & .74 & .44 & .63 & .48 & .66 & .47 \\
\hline \multirow{3}{*}{$\begin{array}{l}\text { Work in } \\
\text { Metropolitan } \\
\text { Areas }\end{array}$} & 2010 & .92 & .27 & .96 & .19 & .92 & .27 & .93 & .26 & .87 & .34 & .75 & .43 \\
\hline & 2000 & .93 & .25 & .95 & .23 & .94 & .24 & .94 & .24 & .86 & .34 & .75 & .43 \\
\hline & 1990 & .94 & .24 & .95 & .21 & .93 & .25 & .94 & .24 & .90 & .30 & .72 & .45 \\
\hline \multirow{3}{*}{$\begin{array}{l}\text { Years since } \\
\text { Migration }\end{array}$} & 2010 & 15.28 & 9.72 & 25.73 & 11.20 & 22.75 & 10.14 & 17.88 & 10.77 & 18.05 & 12.16 & - & - \\
\hline & 2000 & 13.45 & 9.75 & 19.70 & 10.07 & 17.41 & 8.26 & 15.34 & 9.82 & 15.96 & 11.56 & - & - \\
\hline & 1990 & 13.17 & 10.54 & 14.14 & 8.40 & 10.65 & 6.93 & 12.71 & 9.46 & 13.75 & 10.06 & - & - \\
\hline \multirow{3}{*}{ Observations } & 2010 & \multicolumn{2}{|c|}{2,930} & \multicolumn{2}{|c|}{558} & \multicolumn{2}{|c|}{866} & \multicolumn{2}{|c|}{4,354} & \multicolumn{2}{|c|}{81,411} & \multicolumn{2}{|c|}{428,600} \\
\hline & 2000 & \multicolumn{2}{|c|}{8,710} & \multicolumn{2}{|c|}{2,299} & 3 , & & & 166 & 316 & & &, 150 \\
\hline & 1990 & 4, & & 1, & & 2, & & 8,2 & & 189 & 932 & 2,01 & ,309 \\
\hline
\end{tabular}

Note: The earnings have been adjusted for inflation and expressed in 2010 dollars. 
Table 2. Regression Results

\begin{tabular}{|c|c|c|c|c|c|c|c|c|c|c|c|}
\hline \multirow{2}{*}{ Variables } & \multirow{2}{*}{ Year } & \multicolumn{2}{|c|}{$\begin{array}{c}\text { Mainland } \\
\text { China } \\
\end{array}$} & \multicolumn{2}{|c|}{ Hong Kong } & \multicolumn{2}{|c|}{ Taiwan } & \multicolumn{2}{|c|}{ CHT } & \multicolumn{2}{|c|}{$\begin{array}{c}\text { Other } \\
\text { Immigrants }\end{array}$} \\
\hline & & Coeff. & S.E. & Coeff. & S.E. & Coeff. & S.E. & Coeff. & S.E. & Coeff. & S.E. \\
\hline \multirow{3}{*}{ Education } & 2010 & $.087^{* *}$ & .005 & $.110^{* *}$ & .013 & $.145^{* *}$ & .017 & $.095^{* *}$ & .005 & $.073^{* *}$ & .001 \\
\hline & 2000 & $.073^{* *}$ & .003 & $.114^{* *}$ & .007 & $.111^{* *}$ & .007 & $.084^{* *}$ & .002 & $.067^{* *}$ & .000 \\
\hline & 1990 & $.046^{* *}$ & .003 & $.057^{* *}$ & .006 & $.051^{* *}$ & .005 & $.052^{* *}$ & .002 & $.055^{* *}$ & .000 \\
\hline \multirow{3}{*}{ Experience } & 2010 & $.036^{* *}$ & .007 & $.040^{* *}$ & .016 & $.059^{* * *}$ & .012 & $.039^{* *}$ & .006 & $.040^{* *}$ & .001 \\
\hline & 2000 & $.020^{* *}$ & .004 & $.038^{* *}$ & .007 & $.042^{* *}$ & .006 & $.029^{* *}$ & .003 & $.033^{* *}$ & .001 \\
\hline & 1990 & $.026^{* *}$ & .005 & $.032^{* *}$ & .009 & $.045^{* *}$ & .008 & $.029^{* *}$ & .004 & $.044^{* *}$ & .001 \\
\hline \multirow{3}{*}{ Experience $^{2} / 100$} & 2010 & $-.066^{* *}$ & .014 & $-.068^{* *}$ & .033 & $-.122^{* *}$ & .029 & $-.070^{* *}$ & .012 & $-.063^{* *}$ & .003 \\
\hline & 2000 & $-.045^{* *}$ & .008 & $-.073^{* *}$ & .015 & $-.089^{* *}$ & .015 & $-.062^{* *}$ & .006 & $-.053^{* *}$ & .001 \\
\hline & 1990 & $-.050^{* *}$ & .009 & $-.064^{* *}$ & .020 & $-.092^{* *}$ & .021 & $-.057^{* *}$ & .008 & $-.068^{* *}$ & .001 \\
\hline \multirow{3}{*}{$\begin{array}{l}\text { Log Usual Hours } \\
\text { Worked Per Week }\end{array}$} & 2010 & $.676^{\prime \prime}$ & .072 & $1.258^{* *}$ & .186 & $1.172^{* *}$ & .165 & $.846^{* \prime \prime}$ & .067 & $.989^{* 17}$ & .022 \\
\hline & 2000 & $.645^{* *}$ & .041 & $.797^{* *}$ & .086 & $.749^{* *}$ & .085 & $.694^{* *}$ & .035 & $.791^{* *}$ & .008 \\
\hline & 1990 & $.519^{* *}$ & .035 & $.828^{* *}$ & .138 & $.865^{* *}$ & .120 & $.639^{* *}$ & .050 & $.812^{* *}$ & .011 \\
\hline \multirow{3}{*}{$\begin{array}{l}\text { Married with } \\
\text { spouse present }\end{array}$} & 2010 & .122 & .042 & $.117^{*}$ & .071 & $.138^{*}$ & .074 & $.127^{*}$ & .033 & $.201^{* \prime \prime}$ & .007 \\
\hline & 2000 & $.173^{* *}$ & .022 & $.165^{* *}$ & .038 & $.151^{* *}$ & .034 & $.172^{* *}$ & .017 & $.225^{* *}$ & .003 \\
\hline & 1990 & $.165^{* *}$ & .027 & $.314^{* *}$ & .045 & $.360^{* *}$ & .045 & $.267^{* *}$ & .023 & $.240^{* *}$ & .004 \\
\hline \multirow{3}{*}{$\begin{array}{c}\text { Work in } \\
\text { Metropolitan } \\
\text { Areas }\end{array}$} & 2010 & $.165^{* *}$ & .057 & $.390^{* *}$ & .139 & .100 & .142 & $.182^{* *}$ & .051 & $.111^{* *}$ & .009 \\
\hline & 2000 & $.063^{*}$ & .034 & $.220^{* *}$ & .087 & .071 & .054 & $.090^{* *}$ & .028 & $.123^{* *}$ & .004 \\
\hline & 1990 & $.101^{* *}$ & .044 & $.312^{* *}$ & .092 & $.171^{* *}$ & .067 & $.151^{* *}$ & .038 & $.177^{* *}$ & .006 \\
\hline \multirow{3}{*}{$\begin{array}{l}\text { Years since } \\
\text { Migration }\end{array}$} & 2010 & $.019^{* * *}$ & .005 & .014 & .011 & $.023^{* *}$ & .010 & $.021^{* *}$ & .004 & $.010^{* *}$ & .001 \\
\hline & 2000 & $.023^{* * *}$ & .003 & .007 & .006 & $.017^{* *}$ & .006 & $.024^{* *}$ & .002 & $.013^{* *}$ & .000 \\
\hline & 1990 & $.045^{* *}$ & .003 & $.039^{* *}$ & .008 & $.042^{* *}$ & .009 & $.041^{* *}$ & .003 & $.021^{* *}$ & .001 \\
\hline \multirow{3}{*}{$\begin{array}{l}\text { English Very } \\
\text { Well }\end{array}$} & 2010 & .075 & .094 & -.070 & .096 & -.023 & .093 & .008 & .054 & $-.051^{* * *}$ & .009 \\
\hline & 2000 & $.209^{* *}$ & .051 & -.048 & .045 & -.017 & .054 & $.069^{* *}$ & .029 & $-.057^{* *}$ & .004 \\
\hline & 1990 & .012 & .052 & -.040 & .080 & $.197^{* *}$ & .083 & .043 & .038 & $-.081^{* *}$ & .005 \\
\hline \multirow{3}{*}{ English Well } & 2010 & $-.183^{* *}$ & .094 & $-.193^{*}$ & .114 & -.181 & .114 & $-.216^{* *}$ & .058 & $-.268^{* *}$ & .010 \\
\hline & 2000 & -.021 & .052 & $-.253^{* *}$ & .053 & -.073 & .057 & $-.105^{* *}$ & .031 & $-.215^{* *}$ & .005 \\
\hline & 1990 & $-.240^{* *}$ & .053 & $-.287^{* *}$ & .086 & .061 & .089 & $-.161^{* *}$ & .039 & $-.207^{* *}$ & .006 \\
\hline \multirow{3}{*}{ English Not Well } & 2010 & $-.533^{* *}$ & .103 & -.226 & .173 & $-.375^{* * 1}$ & .178 & $-.540^{* *}$ & .070 & $-.358^{* *}$ & .011 \\
\hline & 2000 & $-.408^{* *}$ & .055 & $-.398^{* *}$ & .078 & $-.259^{* *}$ & .076 & $-.468^{* *}$ & .036 & $-.322^{* *}$ & .005 \\
\hline & 1990 & $-.570^{* *}$ & .056 & $-.583^{* *}$ & .108 & $-.331^{* *}$ & .112 & $-.540^{* *}$ & .045 & $-.377^{* *}$ & .007 \\
\hline \multirow{3}{*}{$\begin{array}{l}\text { English Not At } \\
\text { All }\end{array}$} & 2010 & $-.650^{* *}$ & .116 & -.633 & .378 & $-.450^{* * *}$ & .184 & $-.667^{* *}$ & .086 & $-.374^{* *}$ & .015 \\
\hline & 2000 & $-.452^{* *}$ & .064 & -.279 & .176 & -.429 & .279 & $-.529^{* *}$ & .050 & $-.373^{* *}$ & .007 \\
\hline & 1990 & $-.630^{* *}$ & .064 & $-1.011^{*}$ & .025 & -.081 & .228 & $-.608^{* *}$ & .064 & $-.499^{* *}$ & .000 \\
\hline \multirow{3}{*}{ Constant } & 2010 & $1.538^{* *}$ & .298 & -.997 & .773 & $-1.355^{*}$ & .700 & $.795^{* *}$ & .280 & $.537^{* * *}$ & .083 \\
\hline & 2000 & $1.918^{* *}$ & .174 & $.896^{* *}$ & .355 & $1.061^{* *}$ & .198 & $1.591^{* *}$ & .143 & $1.401^{* *}$ & .032 \\
\hline & 1990 & $2.638^{* *}$ & .157 & $1.163^{* *}$ & .538 & $.911^{*}$ & .476 & $2.027^{* *}$ & .204 & $1.235^{* *}$ & .042 \\
\hline \multirow{3}{*}{$\bar{R}^{2}$} & 2010 & \multicolumn{2}{|c|}{0.485} & & & & & & & 0.4 & \\
\hline & 2000 & 0.4 & & & & & & & & 0.3 & \\
\hline & 1990 & 0.4 & & & & & & & & 0.3 & \\
\hline & 2010 & 2,9 & & & & & & & & 81, & \\
\hline Observations & 2000 & 8,7 & & & & & & & & 316 , & 007 \\
\hline & 1990 & 4,6 & & & & & & & & 189, & 932 \\
\hline
\end{tabular}

Note: Robust standard errors are reported as S.E. $*$ and $* *$ indicate that estimate is statistically significant at the $10 \%$ and $5 \%$ level. Individuals of zero earnings are excluded from the sample. Although estimated coefficients of Year Since Migration $2 / 100$ are not reported, all have negative signs and significant at $5 \%$ level. 
Table 3. Decomposition Results

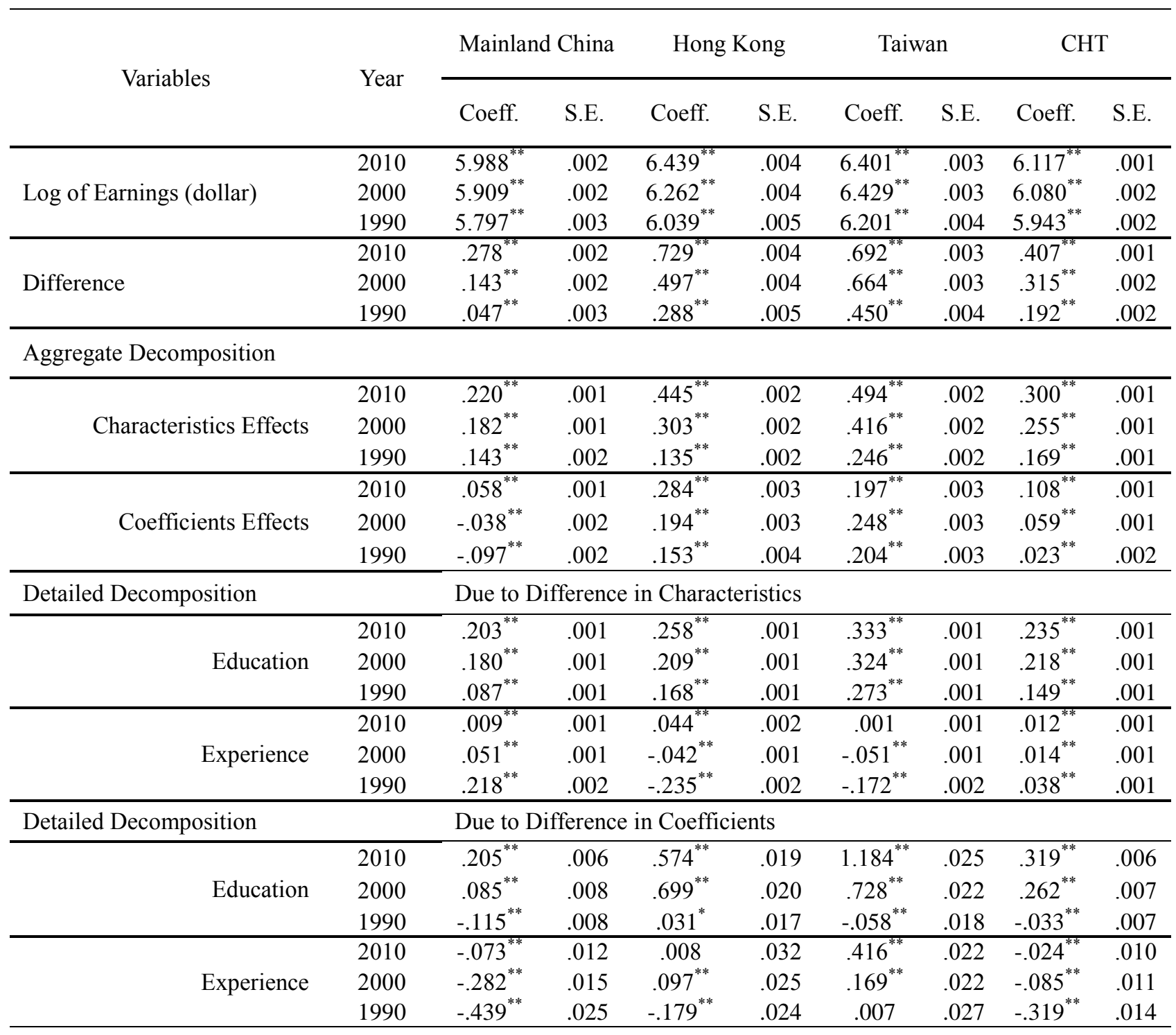

Note: Robust standard errors are reported as S.E. * and ** indicate that estimate is statistically significant at the $10 \%$ and 5\% level. Log of earnings of other immigrants are 5.710, 5.766, and 5.751 for 2010, 2000 and 1990, respectively. Difference $=\log$ earnings of country/region $-\log$ earnings of other immigrants. For example, the difference between mainland China and other immigrants in 2010 is $.278=5.988-5.710$. In detail decomposition, I only report two variables. Others are less important but available upon request. 
Table 4. Cohort Analysis and Aging Effect Results

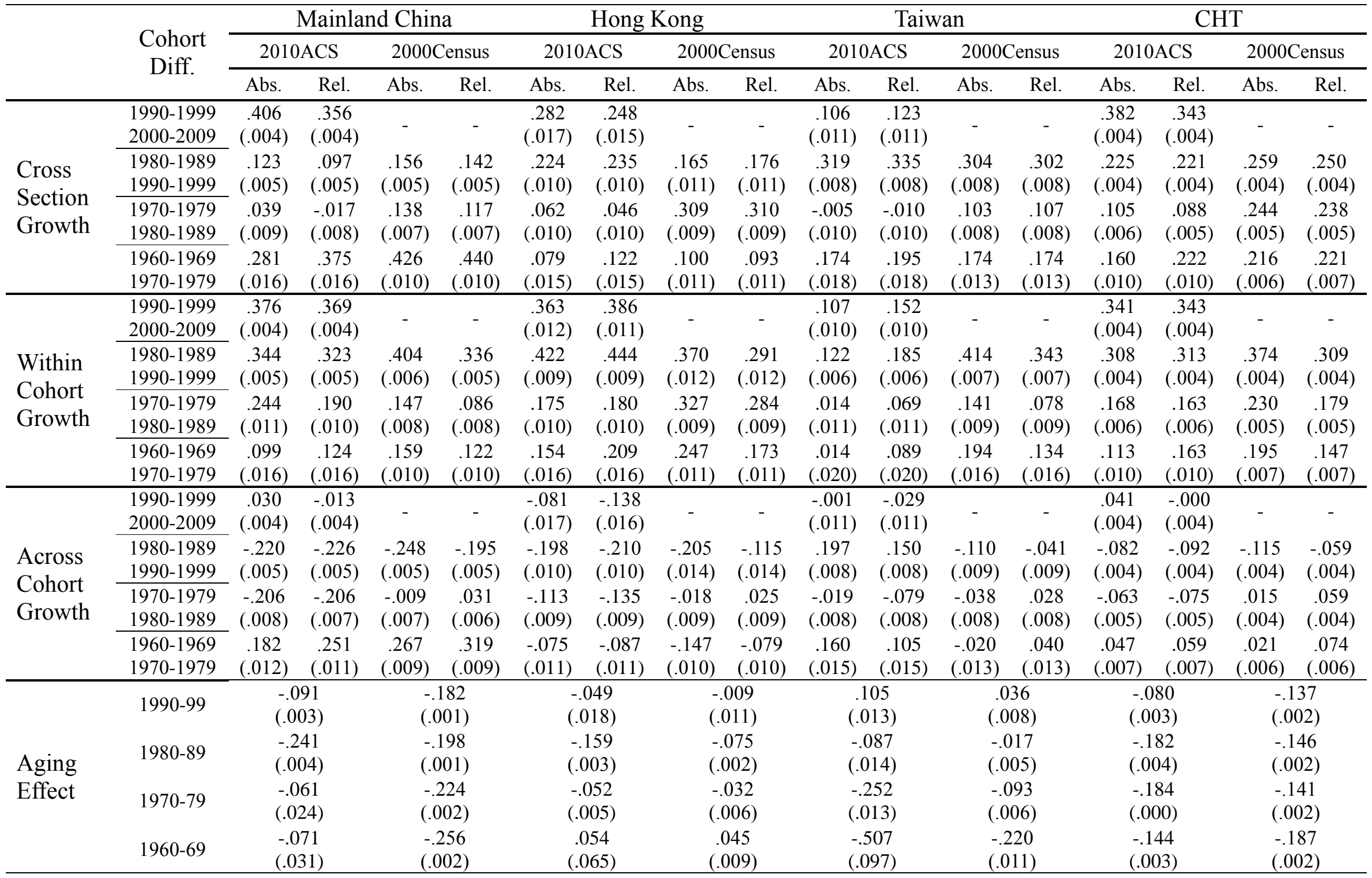

Note: Standard errors are reported in parentheses. The second column shows the difference between two adjacent 10 -year cohorts. For example, the first row of Cross Section Growth reports "1990-1999 cohort" minus "2000-2009 cohort". The coefficient is .356 for mainland China using relative earnings in 2010 ACS. 
Relative Wages to Natives

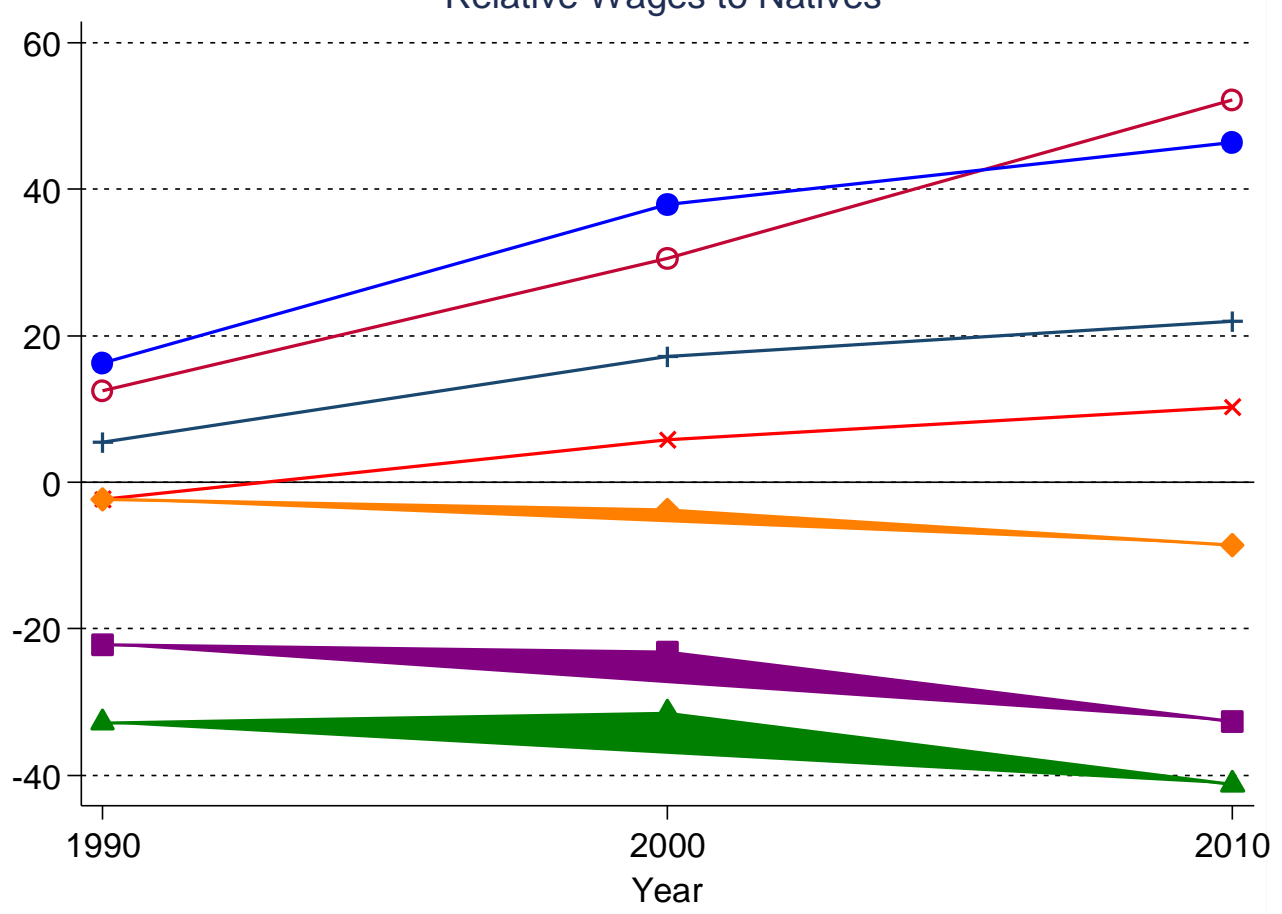

U.S.-Earned Degrees

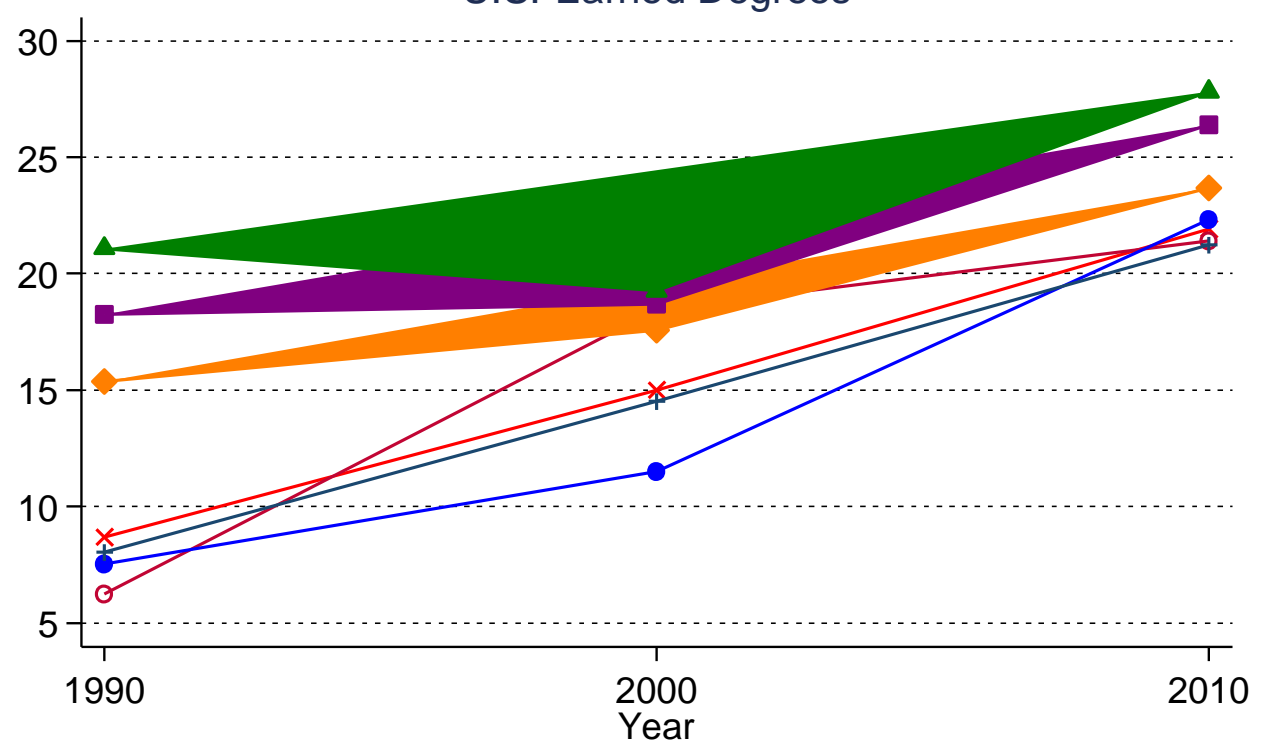

\begin{tabular}{|ll|}
\hline$*$ Mainland China & Hong Kong \\
Taiwan & CHT \\
Other Immigrants & \\
Mexico &
\end{tabular}

Figure 1. Relative Wages and U.S.-Earned Degrees 